\section{Studies on the microbial diversity of salted fishes under aerobic conditions}

\author{
Lawrance Anbu Rajan, Toms C. Joseph, \\ Nirmala Thampuran, Roswin James \\ Microbiology, Fermentation and \\ Biotechnology Division, Central Institute \\ of Fisheries Technology, Cochin, Kerala, \\ India
}

\begin{abstract}
A total of 93 isolates of halophilic and moderately halophilic bacteria were isolated from salted fishes, Scoliodon sp. and Thrissina thryssa obtained from retail fish outlets in Cochin, Kerala, India. The viable count of the bacteria in Scoliodon sp. and Thrissina thryssa ranged from $10^{3}-10^{6}$ per $\mathrm{g}$. The morphological, biochemical, and physiological investigations were done to characterize the isolates, which showed good salted fish products. ${ }^{10}$ While the microbiology of salted fish has not been studied extensively in the recent past, many different species of moderately halophilic bacteria have been isolated from various habitats such as saline lakes, ${ }^{11}$ hypersaline soils, ${ }^{12}$ and solar salterns. ${ }^{13}$ To our knowledge no studies relating to the bacterial profile of salted Scoliodon sp. and Thrissina thryssa have been done. The aim of this work was to characterize the microbial diversity with the main emphasis on the Bacillus halodurans (B. halodurans) strain.
\end{abstract}

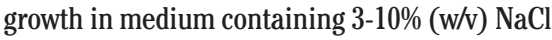
at $37^{\circ} \mathrm{C}$. In Scoliodon sp. the maximum of $87.5 \%$ isolates were Gram-positive cocci and in Thrissina thryssa $95.5 \%$ of the isolates were Gram-positive rods. The optimum conditions such as temperature, $\mathrm{pH}$, and salts $(\mathrm{NaCl})$ were determined. The utilization of organic compounds such as fructose, lactose, glucose, sucrose, arabinose, trehalose, maltose, salicin, mannose, cellobiose, rhamnose, dulcitol, xylose, raffinose, sorbitol, adonitol, inulin, galactose, inositol, mannitol, hydrogen sulfide, nitrate, citrate utilization, MR-VP, triple sugar iron, as well as the hydrolysis of organic compounds such as casein, gelatin, aesculin, starch, Tween 20 , and Tween 80 were also investigated. Moreover, an alkalophilic bacterial strain Bacillus halodurans (B. halodurans) was isolated from Thrissina thryssa and confirmed by $16 \mathrm{~S}$ rDNA analysis. These studies revealed that salted fishes offer an optimal environment for the viable, diverse, potentially and industrially important bacterial community.

\section{Introduction}

Salting and drying has been used for a long time as a method of fish preservation. ${ }^{1}$ Production of canned salted fishes is a traditional activity in the fishing industry in the countries around the Mediterranean Sea. Salting is used for the preservation of fishes from spoilage owing to tissue autolysis and microbial action. ${ }^{2}$ Microbial ecology of salted fish products is influenced markedly by the water activity of the product. The high salt and low moisture contents of the salted fishes have contributed to the extreme halophilic bacteria, which have been the most studied. ${ }^{3,4}$ A broad range of bacteria inhabit salted fishes; among these moderate halophilic bacteria are the dominating flora. Moderately halophilic bacteria are a heterogeneous group of microorganisms characterized by growth over a wide range of salt concentrations (0.5-2.5 M NaCl) ${ }^{5}$ Moderate halophilic bacteria were also recovered from seafoods. ${ }^{67}$ To date, several studies have reported the microbial ecology of hypersaline waters. ${ }^{8,9}$ Few studies have been done regarding the moderately halophilic and halotolerant bacteria in

\section{Materials and Methods}

\section{Sampling and culture conditions}

Six samples each of dried salted fishes like Scoliodon sp. and Thrissina thryssa were obtained from retail fish shops in Cochin, Kerala, India. Salinity of the samples was checked using a salinometer. Ten-gram samples were excised aseptically from each fish and homogenized in $90 \mathrm{~mL}$ of sterile saline water with a Mortar and Pestle and serially diluted up to $10^{-4}$. Then $0.5 \mathrm{~mL}$ of each dilution was used to spread in the growth media. Enumeration and isolation of the bacteria were done on salt agar, high-salt casein agar, and nutrient agar with $3 \% \mathrm{NaCl}$. The plates were incubated at room temperature for 3-7

\section{Characterization of isolates}

All of the 93 isolates were observed for their colony morphology, size, and pigmentation production pattern on the respective media after 2-7 days' incubation and Gram staining was performed according to. ${ }^{14}$ Indole, sulfide production, catalase, oxidase, nitrate reductase activity tests and starch hydrolysis were carried out. ${ }^{15}$ Gelatin hydrolysis and casein hydrolysis were performed as previously described. ${ }^{16,17}$ Motility was observed with the wet mount technique. ${ }^{18}$ Optimal growth temperature, $\mathrm{pH}$, and salt concentration were determined in the nutrient medium with $10 \%$ (w/v) marine salts containing: $\mathrm{NaCl}, 8.1 \mathrm{~g}$; days in sealed polythene bags.
Correspondence: Lawrance Anbu Rajan, Microbiology, Fermentation and Biotechnology Division, Central Institute of Fisheries Technology, Cochin 682 029, Kerala, India.

E-mail: anburajanl@yahoo.co.in

Key words: microbial diversity, salted fishes, aerobic.

Acknowledgements: the authors are grateful to the Director, CIFT, Cochin for providing the necessary facility to carry out this research work; and to the Indian Council for Agricultural Research, New Delhi, India for financial assistance.

Received for publication: 8 May 2010.

Revision received: 22 June 2010.

Accepted for publication: 10 July 2010.

This work is licensed under a Creative Commons Attribution 3.0 License (by-nc 3.0).

(C) Copyright L. Anbu Rajan et al., 2010

Microbiology Research 2010; 1:e5

doi:10.4081/mr.2010.e5

$\mathrm{MgCl}_{2}, 0.7 \mathrm{~g} ; \mathrm{MgSO}_{4}, 0.96 \mathrm{~g} ; \mathrm{CaCl}_{2}, 0.036 \mathrm{~g} ; \mathrm{KCl}$, $0.2 \mathrm{~g} ; \mathrm{NaHCO}_{3}, 0.006 \mathrm{~g}$; and $\mathrm{NaBr}, 0.0026 \mathrm{~g}^{16}$ The $\mathrm{pH}$ range for growth was determined in similar media, with the $\mathrm{pH}$ range of 8.0-10.0. The growth rate was determined in $0.5,2,5$, 10 , and $20 \% \mathrm{NaCl}$ and cultivated at $15,25,30$, 35 and $45^{\circ} \mathrm{C}$. The following compounds were tested as sole carbon sources: glucose, fructose, lactose, mannitol, trehalose, maltose, sucrose, salicin, mannose, cellobiose, rhamnose, dulcitol, xylose, raffinose, sorbitol, adonitol, inulin, galactose, inositol, and arabinose in basal medium with $1 \%(\mathrm{w} / \mathrm{v})$ peptone, $0.5 \%$ $(\mathrm{w} / \mathrm{v})$ yeast extract, $0.001 \%$ (w/v) phenol red, and $10 \%(\mathrm{w} / \mathrm{v})$ marine salts. These isolates will be further studied for their salt tolerance, growth at different $\mathrm{pH}$ range and temperature.

\section{Identification of Bacillus halodurans}

Identification and biochemical characterization of $B$. halodurans using the conventional method was carried out as described by. ${ }^{19}$

\section{Genomic DNA isolation for $16 \mathrm{~S}$ rDNA analysis}

Genomic DNA extraction from B. halodurans was performed as described by. ${ }^{20} 1.5 \mathrm{~mL}$ of the late exponential phase bacterial cells were transferred into a microfuge tube and centrifuged at $10,000 \mathrm{rpm}$ for $5 \mathrm{~min}$ at $4^{\circ} \mathrm{C}$. The supernatant was discarded. The clean cells were suspended in $200 \mu \mathrm{L}$ of lysis buffer and incubated at $37^{\circ} \mathrm{C}$ for $30 \mathrm{~min}$. Then, $30 \mu \mathrm{L}$ of $10 \%$ SDS and $10 \mu \mathrm{L}$ of proteinase $\mathrm{K}$ (20 $\mathrm{mg} / \mathrm{mL}$ ) were added. The tube contents were gently mixed and incubated at $37^{\circ} \mathrm{C}$ for $1 \mathrm{~h}$. An equal volume of phenol:chloroform was added and the tube was centrifuged at $12,000 \mathrm{rpm}$ for 
Table 1. Oligonucleotide primers used for PCR amplification of 165 rDNA.

\begin{tabular}{lcc} 
Primer designation & Requerence \\
$27 \mathrm{f}$ & AGAGTTTGATCMTGGCTCAG & 37 \\
$1525 \mathrm{r}$ & AAGGAGGTGWTCCARCC & 37 \\
\hline
\end{tabular}

Table 2. Growth of microorganisms isolated from Scoliodon sp. and Thrissina thryssa.

\begin{tabular}{|c|c|c|c|c|}
\hline \multirow[t]{2}{*}{ Sample } & \multirow{2}{*}{ No. of sample } & \multicolumn{3}{|c|}{ Average count range(CFU/gm) } \\
\hline & & $\begin{array}{c}\text { Salted agar } \\
\text { media ( } 5 \% \mathrm{NACl})\end{array}$ & $\begin{array}{l}\text { Nutrient agar } \\
\text { media }(3 \% \mathrm{NACl})\end{array}$ & $\begin{array}{l}\text { High salt } \\
\text { casein agar media } \\
(25 \% \mathrm{NACl})\end{array}$ \\
\hline Shark & 6 & $3.3 \times 10^{4}-5.5 \times 10^{4}$ & $4.2 \times 10^{4}-9.7 \times 10^{4}$ & $1.1 \times 10^{4}-1.2 \times 10^{4}$ \\
\hline Anchovies & 6 & $1.1 \times 10^{4}-1.7 \times 10^{4}$ & $1.9 \times 10^{4}-2.7 \times 10^{4}$ & - \\
\hline
\end{tabular}

Table 3. Number of isolates from Scoiodon sp. and Thrissina thryssa.

\begin{tabular}{lcccc} 
Sample & Total & $\begin{array}{c}\text { Salted agar } \\
(5 \% \mathrm{NaCl})\end{array}$ & $\begin{array}{c}\text { No. of isolates } \\
\text { Nutrient agar with } \\
(3 \% \mathrm{NaCl})\end{array}$ & $\begin{array}{c}\text { High salt } \\
\text { casein agar } \\
(25 \% \mathrm{NaCl})\end{array}$ \\
Shark & 38 & 17 & 21 & - \\
Anchovies & 55 & 15 & 30 & 10 \\
\hline
\end{tabular}

5 min at $4^{\circ} \mathrm{C}$. The supernatant was transferred to a new microfuge tube. Twice the volume of cold absolute ethanol was added to the supernatant and gently mixed to precipitate the DNA. The tube was then centrifuged at 12,000 rpm for $5 \mathrm{~min}$ at $4^{\circ} \mathrm{C}$. The supernatant was discarded. The precipitated DNA was washed with $500 \mu \mathrm{L}$ of $70 \%$ ethanol, and dried at $37^{\circ} \mathrm{C}$ for 30 min. The DNA pellet was resuspended with 50 $\mu \mathrm{L}$ of TE buffer and kept overnight at $4^{\circ} \mathrm{C}$ to dissolve the precipitated DNA.

\section{Polymerase chain reaction amplifi- cation of $16 \mathrm{~S}$ rDNA}

The 16S rDNA of halophilic bacterium isolate was amplified by PCR using primers $27 \mathrm{f}$ and $1525 \mathrm{r}$ (Table 1). The PCR was performed using a PTC-150 Mini cycler (MJ Research, Waltham, MA, USA) with a primary heating step for 2 min at $95^{\circ} \mathrm{C}$, followed by 30 cycles of denaturation for $20 \mathrm{sec}$ at $95^{\circ} \mathrm{C}$, annealing for $60 \mathrm{sec}$ at $55^{\circ} \mathrm{C}$, and extension for $2 \mathrm{~min}$ at $72^{\circ} \mathrm{C}$, then followed by a final extension step for $7 \mathrm{~min}$ at $72^{\circ} \mathrm{C}$. Each $25 \mu \mathrm{L}$ reaction mixture contained $2 \mu \mathrm{L}$ of genomic DNA, $14.25 \mu \mathrm{L}$ of MilliQ water, $2.5 \mu \mathrm{L}$ of $10 \times$ buffer $(100 \mathrm{mM}$ Tris-HCl, pH 8.3; $500 \mathrm{mM} \mathrm{KCl}), 1.5 \mu \mathrm{L}$ of $\mathrm{MgCl}_{2}$ $(25 \mathrm{mM}), 2.5 \mu \mathrm{L}$ of dNTP's mixture (dATP, dCTP, dGTP, dTTP at $10 \mathrm{mM}$ concentration), 1.0 $\mu \mathrm{L}$ of each primer $(20.0 \mathrm{pmoles} / \mu \mathrm{L})$, and 0.25 $\mu \mathrm{L}$ of Taq DNA polymerase (MBI Fermentas, USA). The PCR-amplified product was analyzed on $1 \%$ agarose gel containing ethidium bromide $(0.5 \mu \mathrm{g} / \mathrm{mL})$ and $1 \mathrm{~kb}$ DNA molecular weight marker (MBI Fermentas), and documented using a gel documentation system (Alpha Imager 1220, Alpha Innotech Corporation, San Leandro, CA, USA).

Sequencing and in silico analysis of polymerase chain reaction amplicon

The PCR amplicon was purified by the MinElute Gel purification Kit (Qiagen, Hilden, Germany) and was sequenced on an $\mathrm{ABI}$ PRISM 377 genetic analyzer (Applied Biosystems Inc., Foster City, CA, USA). The nucleotide sequences obtained were compared against database sequences using BLAST $^{21}$ provided by NCBI (http://www.ncbi. nlm.nih.gov) and were aligned and clustered using the CLUSTAL-X version 1.81 program. ${ }^{22}$

\section{Results}

\section{Isolation of microorganisms}

About $75 \%$ of the isolates obtained from both the Scoliodon sp. and Thrissina thryssa samples were grown optimally in a $3-10 \% \mathrm{NaCl}$ media and were thus considered as moderate halophiles..$^{23}$ Scoliodon sp. and Thrissina thrys$s a$ were analyzed for the growth of bacteria by inoculating the sample on salted agar media, $(5 \% \mathrm{NaCl})$, nutrient agar $(3 \% \mathrm{NaCl})$, and highsalt casein media $(25 \% \mathrm{NaCl})$. The counts observed for the samples in two different media are given in Table 2. Nutrient agar with $3 \% \mathrm{NaCl}$ had an elevated count in both the samples analyzed and Scoliodon sp. had a higher count than Thrissina thryssa. A total number of 93 isolates were randomly selected for characterization. The source of the isolates are given in Table 3 .

\section{Morphological observations}

Of the 48 isolates from dried shark, 42 (87.5\%) were Gram-positive cocci and the remaining 6 (12.5\%) were Gram-positive rods.
Table 4. Characteristic features of the bacterial isolates.

Morphological and $\quad$ No. of isolates
phenotypic characters

Morphology

Rods

Cocci

Colony pigment

White

20

Yellow

Cream

Pink

Orange

32

Salts: growth at

$0.5 \%$

$2.0 \%$

$5.0 \%$

$10.0 \%$

$20.0 \%$

$\mathrm{pH}$ : growth at

$\mathrm{pH} 8$

pH 9

pH 10

1

Temperature: growth at

$15^{\circ} \mathrm{C}$

$25^{\circ} \mathrm{C}$

$30^{\circ} \mathrm{C}$

$35^{\circ} \mathrm{C}$

$40^{\circ} \mathrm{C}$

Utilization of carbohydrates

Glucose

Fructose

Arabinose

Mannitol

Trehalose

Lactose

Maltose

Sucrose

Salicin

Mannose

Cellobiose

Rhamnose

Dulcitol

Xylose

Raffinose

Sorbitol

Adonitol

Inulin

Galactose

Inositol

Cytochrome oxidase

Catalase

Gelatin hydrolysis

Casein hydrolysis

Starch hydrolysis

39

63

89

93

79

Indole production

Motility

Hydrogen sulfide production

Nitrate reduction

Citrate utilization

Methyl red

13

9

5

13

9

2

12

15

9

10

8

5

10

14

11

13

7

11

6

8

50

93

12

17

27

Nil

20

18

27

Voges Praskeur

11

17

Triple sugar iron agar test 
In the case of isolates from dried anchovies, of the 45 isolates, 43 (95.5\%) were Gram-positive rods and 2 (4.4\%) were Gram-positive cocci (Table 4).

\section{Pigmentation pattern}

All isolates were observed for their colony color. Of the 93 isolates, $21.5 \%$ were whitish, $27.9 \%$ were yellowish, $34.4 \%$ were creamy, $13.9 \%$ were pinkish, and $1 \%$ were orange in color.

\section{Phenotypic characterization of isolates}

Of 93 total isolates, the following sugars were utilized: $5.3 \%$ arabinose, $13.9 \%$ glucose, 9.6\% fructose, $2.1 \%$ lactose, $9.6 \%$ trehalose, $13.9 \%$ mannitol, $13 \%$ maltose, $16 \%$ sucrose, 9.6\% salicin, $10.7 \%$ mannose, $8.6 \%$ cellobiose, $5.3 \%$ rhamnose, $10.7 \%$ dulcitol, $15 \%$ xylose, $11.8 \%$ raffinose, $14 \%$ sorbitol, $7.5 \%$ adonitol, $11.8 \%$ inulin, $6.4 \%$ galactose, and $8.6 \%$ inositol. Moreover, $21.5 \%$ of the isolates were found to be motile. $19.3 \%$ isolates revealed positive result for $\mathrm{H} 2 \mathrm{~S}$. About $29 \%$ of the isolates were found to reduce nitrate. $11.8 \%$ of the isolates were found to utilize citrate. $18.2 \%$ isolates revealed positive result for Methyl Red test. $22.5 \%$ isolates revealed positive result for Voges Praskeur. 22.5\% isolates exhibited positive result for triple sugar iron agar test.About $29,18.2$, and $12.9 \%$ of the isolates exhibited a positive result for starch, casein and gelatin hydrolysis, respectively. Out of 48 isolates from the shark samples, all were found to be catalase positive, $56.25 \%$ were oxidase positive, and the remaining $43.75 \%$ were oxidase negative. Of the 45 isolates from the anchovy samples, all were catalase positive, and in the case of the cytochrome oxidase test, $51.1 \%$ were positive and $48.8 \%$ were negative. No isolates produced indole from tryptophan.

\section{Growth range and optimal growth conditions}

Of the 93 isolates, $80.6 \%$ were grown in $10 \%$ $\mathrm{NaCl}, 77.4 \%$ in $2 \% \mathrm{NaCl}, 75.2 \%$ in $0.5 \% \mathrm{NaCl}$, $83.8 \%$ in $5 \% \mathrm{NaCl}$, and $10.75 \%$ in $20 \% \mathrm{NaCl}$. The optimum $\mathrm{NaCl}$ range for growth was $2-10 \%$ among the 93 isolates. $\mathrm{pH}$ range for growth also varied among the isolates; $95.6 \%$ of the 93 isolates were found to have good growth at $\mathrm{pH} 8$, $91.3 \%$ at $\mathrm{pH} 9$, and $60.21 \%$ at $\mathrm{pH} 10$. The optimum range of $\mathrm{pH}$ was found to be 7-9. The optimal growth temperature for the 93 isolates was determined to be $30^{\circ} \mathrm{C}$. The isolates thus have a wide growth range, both in salt concentration and $\mathrm{pH}$.

\section{Isolation and identification of \\ Bacillus halodurans}

Morphological, physiological, and biochemical characterization of $B$. halodurans were found to be: a Gram-positive, spore-forming rod; motile; oxidase positive; catalase negative; and utilized glucose, fructose, galactose, sucrose, lactose, and arabinose. Hydrolysis of Tween 40, 60, casein, gelatin, and starch is obtained but the hydrolysis of Tween 20 and reduction of nitrate were not observed. The isolate also exhibited good growth on nutrient agar plates with $15 \% \mathrm{NaCl}$ and at $\mathrm{pH} 10.0$. Moreover, good growth was observed in the temperature range of $15-55^{\circ} \mathrm{C}$. These properties support the previous report for the identification of $B$. halodurans.$^{19}$ Furthermore, the $B$. halodurans isolate was confirmed by $16 \mathrm{~S}$ rDNA analysis. The sequence of the $16 \mathrm{~S}$ rDNA gene 1502 bp (Figure 1) of our isolate showed 100\% identity to that of the previously reported $B$. halodurans C-125 (BA000004) ${ }^{24}$ and B. halodurans MS-2-5 (AB359904). ${ }^{25}$ Thus, the bacterial strain was identified and confirmed as B. halodurans, on the basis of these results. The $16 \mathrm{~S}$ rDNA sequence generated in this study was submitted to GenBank and has been given the accession no. GU367604.

\section{Discussion}

Several species of moderately halophilic eubacteria, obtained from diverse natural saline habitats, have been isolated and described in recent years. ${ }^{4}$ Microbial diversity of salted Scoliodon sp. and Thrissina thryssa in this study was the first in saline ecosystems to be studied in detail from a microbiological standpoint. In view of the great commercial importance of the halophilic and moderate halophilic bacteria, it is surprising how little research has been done to study the microbiology of salted fishes. Our primary interest was in characterizing the microorganisms with the potential value of biotechnological interest. Presently there are only nominal reports of the isolation of bacteria from salted foods. ${ }^{10}$ In our study, we isolated 147 bacterial strains, of which 93 of both halophilic and moderately halophilic bacteria were characterized in detail. The majority of the Gram-positive cocci (87.5\%) were found in Scoliodon sp. whereas the maximum numbers of Gram-positive rods (95.5\%) were observed in Thrissina thryssa. These results agree with those reported by other authors in salted $\operatorname{cod}^{10}$ and other cured food commodities such as smoked catfish, ${ }^{26}$ fermented sausages, ${ }^{27}$ and cured meats. ${ }^{28}$ Gram-positive cocci are the dominant bacterial survivors in salted fishes. ${ }^{29}$ Staphylococcus aureus and Staphylococcus xylosus have been found in green salted and dried salted products, respectively. ${ }^{30}$ All the isolates in this study were found to use various organic compounds including sugars as substrates and should be considered chemoorganotrophs. For the first time, we have isolated an industrially import-

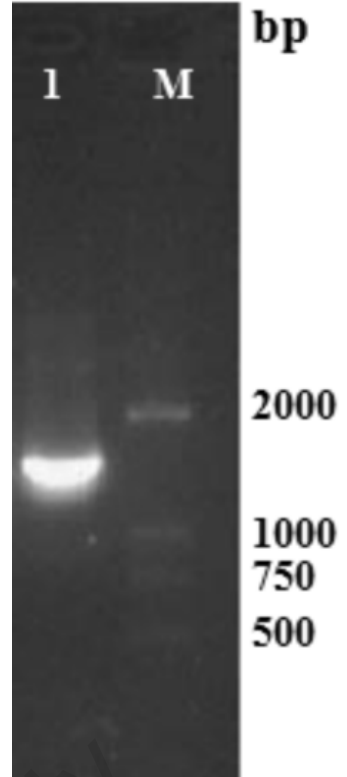

Figure 1. 16S rDNA amplicon of Bacillus balodurans. Lane M: -1 kb DNA Ladder. Lane 1: Amplicon of 16S rDNA (1,502 bp).

alkalophilic B. halodurans strain from Thrissina thryssa. Previous studies reported the isolation and identification of Marinococcus and Halobacillus strains from other saline environments, including athalassohaline and thalassohaline lakes and marine waters. $^{31,32}$ In our study, about $75 \%$ of the isolates from both salted fish samples revealed optimal growth in $3-10 \% \mathrm{NaCl}$ media and were thus considered as moderate halophiles. ${ }^{33}$ Recent research on different hypersaline habitats focused on the screening of new bacteria with potential applications in biotechnology. ${ }^{34}$ The potential industrial use of these microorganisms has been highlighted for the production of compatible solutes, biopolymers, and bioremediation processes ${ }^{33,34}$ prompting us to screen our collection of halophiles for molecules of industrial interest. Moreover, extensive studies on these bacteria will certainly offer different potential applications in various pharmacochemical industries..$^{35,36}$

\section{Conclusions}

Based on the results, it can be concluded that the identification and characterization of halophilic and moderately halophilic bacteria presenting in salted Scoliodon sp. and Thrissina thryssa have opened several possibilities for future research in the field of industrial biotechnology and microbial spoilage aspects. 


\section{References}

1. Moutinho M0. Bacalhau na alimentacao do povo in Historia da Pesca do Bacalhau: Editorial Estampa Lisboa, 1985, pp 149-84.

2. Filsinger BE. Effect of pressure of salting and ripening process of anchovies Engraulis anchoita. J Food Sci 1987;52: 91922.

3. Chandler RE. The effect of temperature and water activity on microbial growth rate and food spoilage. Ph.D. Thesis, University of Tasmania, 1988.

4. Vilhelmsson 0, Hafsteinsson H, Kristjansson JK. Isolation and characterization of moderately halophilic bacteria from fully cured salted cod (bachalao). Int J Appl Bacteriol 1996;81:95-103.

5. Kushner DJ. Life in high salt and solute concentrations: halophilic bacteria. In: microbial life in extreme environments. Kushner DJ, ed. London: Academic Press, 1978, pp 317-68.

6. Yoon JH, Kang SS, Lee KC, et al. Bacillus jeotgali sp. nov., isolated from jeotgal, Korean traditional fermented seafood. Int J Syst Evol Microbiol 2001;51:1087-92.

7. Brisou J, Courtois B, Denis F. Microbiological study of a hypersaline lake in French Somaliland. Appl Microbiol 1973; 27:819-22.

8. Nissenbaum A. The microbiology and biogeochemistry of the Dead Sea. Microb Ecol 1975;2:139-61.

9. Post FJ. The microbial ecology of the Great Salt Lake. Microb Ecol 1977;3:145-65.

10. Vilhelmsson 0, Hafsteinsson H, Kristjansson JK. Extremely halotolerant bacteria characteristic of fully cured and dried cod. Int J Food Microbiol 1997;36:163-70.

11. Oren A. Halobacterium sodomense sp. nov., a Dead Sea halobacterium with an extremely high magnesium requirement. Int J Syst Bacteriol 1983;33:381-6.

12. Quesada E, Ventosa A, Rodriguez F, et al. Numerical taxonomy of moderately halophilic Gram negative bacteria from hypersaline soils. J Gen Microbiol 1983; 129 : 2649-57.

13. Mathrani IM, Boone DR. Isolation and characterization of a moderately halo philic methanogen from a solar saltern. Appl Environ Microbiol 1985;50:140-3.

14. Gram HC. Uber die isolierte Farbung der Schizomyceten in Schnitt und Trockenpraparaten. Fortsch Medizin 1884;2:185-9.
15. Smibert RM, Krieg NR. Phenotypic characterization. In: Methods for General and Molecular Bacteriology. Gerhardt P, Murray RGE, Wood WA, Krieg NR, eds. Washington: American Society for Microbiology, 1994, pp 607-54.

16. Rodriguez Valera F, Ruiz Berraquero A, Cormenzana R. Isolation of extremely halophilic bacteria able to grow in defined inorganic media with single carbon sources. J Gen Microbiol 1980;119:535-8.

17. Cowan ST, Steel KJ. Manual for the identification of medical bacteria. Cambridge: Cambridge University Press, 1974.

18. Murray RGE, Doetsch RN, Robinow CF. Determinative and cytological light microscopy. In: Methods for General and Molecular Bacteriology. Gerhardt P, Murray RGE, Wood WA, Krieg NR, eds. Washington: American Society for Microbiology, 1994, pp 21-41.

19. Nielsen P, Fritze D, Priest F. Phenetic diversity of alkaliphilic Bacillus strains: proposal for nine new species. Microbiology 1995;141:1745-61.

20. Moore DD. Preparation and analysis of DNA. In: Current Protocols in Molecular Biology. Ausubel FM, Brent R, Kingston RE, Moore DD, Seidman JG, Smith JA, Struhl K, eds. New York: John Wiley, 1995, pp 2-1 to 2-12.

21. Altschul SF, Gish W, Miller W, et al. Basic local alignment search tool. J Mol Biol 1990;215:403-10.

22. Thompson JD, Gibson TJ, Plewniak F, et al. The CLUSTAL $X$ windows interface: flexible strategies for multiple sequence alignment aided by quality analysis tools. Nucl Acids Res 1997;25:4876-82.

23. Kushner DJ. Microbial life in extreme environments. In: the Bacteria. Woese CR, Wolfe RS, eds. New York: Academic Press, 1985, pp 171-4.

24. Takami H, Horikoshi K. Re-identification of facultatively alkaliphilic Bacillus sp. C125 to Bacillus halodurans. Biosci Biotechnol Biochem 1999;63:943-5.

25. Murakami S, Nagasaki K, Nishimoto H, et al. Purification and characterization of five alkaline, thermotolerant and maltotetraose-producing alpha-amylases from Bacillus halodurans MS-2-5, and production of recombinant enzymes in Escherichia coli. Enzyme Microb Technol 2008;43:321-8.

26. Efiuvwevwere BJO, Ajiboye MO. Control of microbiological quality and shelf-life of catfish (Clarias gariepinus) by chemical preservatives and smoking. J Appl Bacteriol 1996;80:465-70.

27. Nychas GJE, Arkoudelos JS. Staphylococci: Their role in fermented sausages. J Appl Bacteriol 1990;69:167-88.

28. Gardner GA, Kitchell AG. The microbiological examination of cured meats. In: Sampling-Microbiological Monitoring of Environments. Board RR, Lovelock DN, eds. London: Academic Press, 1973, pp 1153.

29. ICMSF, Fish and fish products in Microorganisms In: Foods. Roberts TA, Pitt JI, Farkas J, Grau FH, eds. Vol. 6. London: Blackie Academic and Professional, 1998, pp 130-89.

30. McMeekin TA, Chandler RE, Doe PE, et al. Model for the combined effect of temperature and salt concentration/water activity on the growth rate of Staphylococcus xylosus. J Appl Bacteriol 1997;62:543-50.

31. Grant WD, Kamekura M, McGenity TJ, et al. Class III. Halobacteria class. nov. In: Bergey's Manual of Systematic Bacteriology. Bonne DR, Castenholz RW, eds. New York, NY: Springer, 2001, pp 294-334.

32. Arahal DR, Ventosa A. The family Halomonadaceae. In: the prokaryotes: an evolving electronic resource for the microbial community. Dworkin M, Falkow S, Rosenberg E, Schleifer KH, Stackebrandt E, eds. New York, NY: Springer, 2005.

33. Ventosa A, Marquez MC, Garabito MJ, et al. Moderately halophilic gram-positive bacterial diversity in hypersaline environments. Extremophiles 1998;2:297-304.

34. Margesin R, Schinner F. Potential of halotolerant and halophilic microorganisms for biotechnology. Extremophiles 2001;5: 73-83.

35. Jones BE. Industrial enzymes: do halophiles and alkaliphiles have a role to play. In: Halophilic Microorganisms. Ventosa A, ed. New York, NY: Springer, 2004, pp 27584.

36. Quesada E, Bejar V, Ferrer MR. Moderately halophilic, exopolysaccharide-producing bacteria. In: Halophilic Microorganisms. Ventosa A, ed. New York, NY: Springer, 2004, pp 297-314.

37. Lawson PA, Deutch CE, Collins MD. Phylogenetic characterization of a novel salt tolerant Bacillus species: description of Bacillus dipsosauri sp. nov. J Appl Bacteriol 1996;81:109-12. 